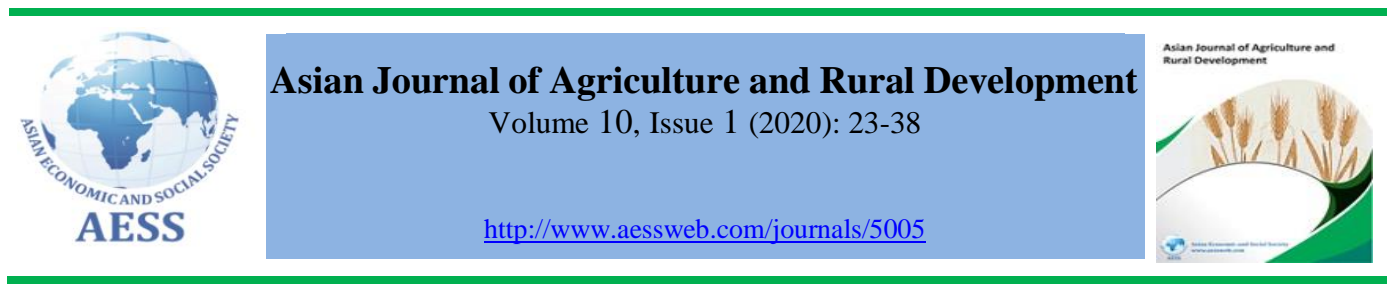

\title{
AN EVALUATION OF MORTALITY OF SITOPHILUS ORYZAE TREATED WITH SELECTED INSECTICIDES VIA FILTER PAPER AND FOOD IMPREGNATED METHOD
}

Ismeazilla, M. B. a, Mohd Rasdi, Z. ${ }^{\text {b }}$, Dzolkhifli, O. c, Norhayu, A. ${ }^{c}$, Izaitul Aida, I. ${ }^{\text {, }}$, Mohd Faizol, K. d, Muhammad Shakir, Z. $^{\text {d, }}$

Nur Fakriyah, A. d,

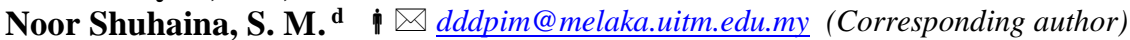

a Post Graduate Students; Faculty of Plantation and Agrotechnology, Universiti Teknologi MARA, Shah Alam, Malaysia

b Associate Professor; Faculty of Plantation and Agrotechnology, Universiti Teknologi MARA Jasin, Melaka, Malaysia

${ }^{\mathrm{c}}$ Lecturer, Faculty of Agriculture, Universiti Putra Malaysia, Serdang, Malaysia

${ }^{d}$ Post Graduate Students; Faculty of Plantation and Agrotechnology, Universiti Teknologi MARA, Shah Alam, Malaysia

\section{ARTICLE HISTORY:}

Received: 31-Aug-2019

Accepted: $13-\mathrm{Feb}-2020$

Online Available: $26-\mathrm{Feb}-$ 2020

\section{Keywords:}

Mortality,

Antifeedants,

Sitophilus oryzae,

Laboratory assessment

\begin{abstract}
Laboratory bioassay were conducted at University Putra Malaysia in order to evaluate the toxicity and the antifeedant activity of five insecticides which is Cypermethrin, Malathion, Prevathon, Rotenone and also Spinosad against the adult of S.oryzae by using the filter paper impregnation and food impregnation method for $1,3,5$ and 7 days. Rotenone found to be effectives in toxicity via filter paper impregnation method based on the LC50 values with $0.003 \%$ while the other was $0.04 \%, 0.017 \%, 0.106 \%$ and $1.109 \%$ were indicated Spinosad, Malathion, Cypermethrin and Prevathon. The less effective was Prevathon. Food impregnation method showed that the effective insecticides was Spinosad with $\mathrm{LC}_{50}$ values $0.001 \%$. The lowest was Prevathon with $\mathrm{LC}_{50}$ values $5.776 \%$. In addition, the other insecticides showed $\mathrm{LC}_{50}$ values was $0.003 \%, 0.05 \%$ and $0.875 \%$ which indicated Malathion, Cypermethrin and Rotenone. For the antifeedant activity via feeding deterrent index (FDI), it showed that, the lowest FDI was Spinosad with $0.535 \%$ while the highest was Rotenone with $1.756 \%$. The other showed $0.63 \%, 0.869 \%$ and $0.949 \%$ indicated Malathion, Cypermethrin and Prevathon respectively. As conclusion, most effective insecticides against adult of S.oryzae was Spinosad because able to control the insect at the prepared concentration in both method.
\end{abstract}

Contribution/ Originality

The current study used the right amount of dosage of insecticides to prevent the losses to rice industries and able to reduce the infestation from the insect during storage. Hence, rice industries will able to control the insect pest and it will increase farmers profit in the rice industrial sector.

DOI: 10.18488/journal.1005/2020.10.1/1005.1.23.38

ISSN (P): 2304-1455/ISSN (E):2224-4433

How to cite Ismeazilla, M. B., Mohd Rasdi, Z., Dzolkhifli, O., Norhayu, A. Izaitul Aida, I., Mohd Faizol, K., Muhammad Shakir, Z., Nur Fakriyah, A. and Noor Shuhaina, S. M. (2020). An evaluation of mortality of Sitophilus oryzae treated with selected insecticides via filter paper and food impregnated method. Asian Journal of Agriculture and Rural Development, 10(1), 23-38.

(C) 2020 Asian Economic and Social Society. All rights reserved. 


\section{INTRODUCTION}

Majority people in the world regard rice as the second most widely grown cereal crop. In developing countries, most of the nation are counting on the rice for food calories and protein (IRRI, 2004). Hence, this rice (Oryzae sativa Linn.) is the most important crop and staple foods around the world's population. In Asia, world's rice is produced and consumed more than $90 \%$ every year (Spencer et al., 2009). For example, Thailand is one of the major rice exporter countries of the world, which is $70 \%$ of export good and values over 114,077 million baht a year (Agroeconomic, 2007). The rice plant is vulnerable to many types of pests, from the seeds to the stored grains. The rice losses occur when milled grains are attacked by stored product insects and the most important one is the rice weevil (Sitophilus oryzae L.) (Coleoptera: Curculionidae). Damaging rice by the $S$. oryzae has seriously affected the availability of food for a large number of people worldwide (Adedire and Lajide, 2003). Without protection, the pests rapidly grow, develop, and damage the stored rice grains. The quality of rice grains is so poor that they do not meet the requirement for normal consumption, exportation, and industrial purposes (Campbell, 2008).

According to Sarker et al. (2006), qualitative and quantitative decline of stored agricultural and animal origin products resulted from invasions of around 70 moths' species, 355 species of mites as well as more than 600 species of beetle pests. Haque et al. (2000) infer that this damage might reduce about $20-30 \%$ in tropical zone and 5 to $10 \%$ in the temperate zone. To manage the pests during storing of rice, the usage of methyl phosphine (PH3) and bromide (MeBr) may lead to several problems (Negahban et al., 2006). Consequently, new strategies on how to manage the pests should be develop in crop industries. For instance, based on Huang and Ho (1998) an extract from higher plants can produced a lot of natural pesticides. These type of products will give a lower toxicity to mammals as well as keep environments safe and also give advantages to human such as medicinal properties (Negahban et al., 2006).

It is important to reduce the population of the insect pests such as Sitophilus species in order to maintain the quantity and quality of stored-product particularly cereals. Both $S$. oryzae (L.) and $S$. granaries (L.) are the most destructive and widespread insect pests of stored grains (Beckett et al., 1994). The quality as well as quantity of the rice grain may loss due to these type of pests which feed inside the rice grain (Kucerova et al., 2003). In order to control the insect pests of stored products the synthetic pesticide has been considered as more effective and accessible (Huang and Subramanyam, 2005).

\section{MATERIAL AND METHODS}

\subsection{Rearing of the test insects}

Colonies of Sitophilus oryzae were obtained from toxicology laboratory stock culture of Universiti Putra Malaysia (UPM) and reared on whole rice grains initially 13 to $14 \%$ moisture content in large aquarium container under the laboratory conditions (Rahman and Talukder, 2006). The subcultures and the tests were carried out under the same conditions. Before rearing process, the rice grains was sterilized by using oven at $50^{\circ} \mathrm{C}$ for 20 to 30 minutes because it consider a normal temperature to sterile the rice grains (Chen, 2003).

For rearing process, each subcultures which is about 200 S.oryzae were placed for every 40 small aquarium covered with muslin cloth that contain rice grains in order to have a similar stage of age which is about 7 to 14 days old. For the feeding and oviposition process, the adults were kept for three days at the room temperature and humidity. Then, these 7 to 14 days old adults were removed from the jar after six days in order to have a new stage of age as mention above. At $27 \pm 1{ }^{\circ} \mathrm{C}$ and with $75 \pm 5 \%$ of Relative Humidity $(\mathrm{RH})$, these eggs were incubated for development and hatching process. These subcultures were kept safe inside a large tray that have been poured with water in 
order to prevent from any small ant and to prevent from any unwanted situation happened. Then, after appropriate 45 days old adult of Sitophilus oryzae were used in the experiment.

\subsection{Procedure for mass rearing of Sitophilus oryzae from UPM's stock culture}

$5 \mathrm{~kg}$ rice grains were used for stock culture. Rice grain was sterilized by using oven at $50^{\circ} \mathrm{C}$ in because consider as normal temperature for sterile the rice grains. Rice grain was placed in tray to let it dry for 10-15 minutes. After fully dried, $200 \mathrm{~g}$ rice grains was placed in small aquarium with 200 S. oryzae from stock culture UPM adult were used for rearing. Then, reared for about two months for adult emergence.

\subsection{Procedures to prepare the test solution in this experiment for impregnated filter paper and food methods}

In this experiment, the test solutions for each of tested insecticide were prepared. Five types of selected insecticides were used are cypermethrin, Malathion, prevathon, spinosad and also rotenone. By using electric weighting balance, all type of insecticides were measured based on the recommended rate that have been calculated in this study by using the equation $M_{1} V_{1}=M_{2} V_{2}$. Hence, the dilution for each tested insecticide have been identified. Solution for total six different concentrations of each insecticide were placed in conical flask, including control after serial dilution were done for eight replication. Then, solutions ready for experiment test.

\subsection{Experimental design}

The experimental design used for this experiment was Completely Randomised Design (CRD) because only two variables used in this experiment which is concentration and type of insecticides.

\subsection{Determination range-finder of the chemicals}

Recommended rate was identified from others previous studied that have working on the same insecticides. The recommended rate as stock solution used was $0.10 \%$ for the Rotenone $12.19 \%$ for the Malathion, $1.00 \%$ for the Cypermethrin, Prevathon and Spinosad respectively in this experiment. Distilled water was used as a control. Hence, pre-test have been done based on each recommended rate and active ingredient for each selected insecticide. The active ingredient was identified based on the type of insecticide used.

By using dilution equation $\left(\mathrm{M}_{1} \mathrm{~V}_{1}=\mathrm{M}_{2} \mathrm{~V}_{2}\right)$, where $\left(\mathrm{M}_{1}\right)$ is referred as concentration in molarity (moles/litres) of the concentrated solution while $\left(\mathrm{M}_{2}\right)$ is the concentration in molarity of the dilute solution which is after solvent have been added. Besides that, $\left(\mathrm{V}_{1}\right)$ is the volume of the concentrated solution while $\left(\mathrm{V}_{2}\right)$ is referred to volume of the dilute solution. Hence, the volume of the concentrated for the pre-test was calculated. $100 \mathrm{ml}$ of distilled water were used for volume of the dilute solution $\left(\mathrm{V}_{2}\right)$. Hence, the difference concentrations of insecticides were tested for each method that has been used for contact toxicity and also for the antifeedant tests. The tables 1 and 2 below showed the different concentration between five insecticides.

Table 1: Five difference concentrations of insecticides were tested on the Sitophilus oryzae for contact toxicity

\begin{tabular}{lcccccc}
\hline \multirow{2}{*}{ Insecticides } & \multirow{2}{*}{ Recommended rate (\%) } & $\mathbf{C}_{\mathbf{1}}$ & $\mathbf{C}_{\mathbf{2}}$ & $\mathbf{C}_{\mathbf{3}}$ & $\mathbf{C}_{\mathbf{4}}$ & $\mathbf{C}_{\mathbf{5}}$ \\
\hline Cypermethrin & 1.00 & 0.500 & 0.250 & 0.125 & 0.062 & 0.031 \\
Malathion & 12.19 & 0.120 & 0.060 & 0.030 & 0.015 & 0.007 \\
Prevathon & 1.00 & 0.120 & 0.060 & 0.040 & 0.020 & 0.010 \\
Rotenone & 0.10 & 0.010 & 0.005 & 0.002 & 0.001 & 0.0006 \\
Spinosad & 1.00 & 0.500 & 0.250 & 0.125 & 0.062 & 0.0312 \\
\hline
\end{tabular}

Note: $\mathrm{C}_{1}-\mathrm{C}_{5}$ indicate the concentration of the insecticides 
Table 2: Five difference concentrations of insecticides were tested on the Sitophilus oryzae for antifeedant test

\begin{tabular}{lcccccc}
\hline \multirow{2}{*}{ Insecticides } & \multirow{2}{*}{ Recommended rate (\%) } & $\mathbf{C}_{\mathbf{1}}$ & $\mathbf{C}_{\mathbf{2}}$ & $\mathbf{C}_{\mathbf{3}}$ & $\mathbf{C}_{\mathbf{4}}$ & $\mathbf{C}_{\mathbf{5}}$ \\
\hline Cypermethrin & 1.00 & 0.125 & 0.062 & 0.031 & 0.015 & 0.008 \\
Malathion & 12.19 & 0.012 & 0.001 & 0.0006 & 0.0003 & 0.0001 \\
Prevathon & 1.00 & 0.120 & 0.080 & 0.040 & 0.020 & 0.010 \\
Rotenone & 0.10 & 0.010 & 0.005 & 0.002 & 0.001 & 0.0006 \\
Spinosad & 1.00 & 0.100 & 0.050 & 0.020 & 0.012 & 0.006 \\
\hline
\end{tabular}

Note: $\mathrm{C}_{1}-\mathrm{C}_{5}$ indicate the concentration of the insecticides

\subsection{Toxicity bioassays}

\subsubsection{Insecticide impregnated filter paper method}

The contact toxicity for each of the insecticides which are Cypermethrin, Malathion, Prevathon, Rotenone and also Spinosad was determined in an impregnated filter paper dip technique for this bioassay. For each solution of the insecticides, $600 \mu \mathrm{l}$ were applied by using pipette to Whatman No.1 filter paper which about $9 \mathrm{~cm}$ diameter. In this experiment, serial dilutions of the insecticides were prepared using distilled water. After that, the distilled water were used as a control purpose and then was allowed to evaporate for 10 minutes in order to make sure it fully dried. Then, the filter paper that have been cooperate with the insecticides were placed in the petri dish with 10 adult insect were released for this experiment. In order to prevent the insects from escaping, the petri dish were sealed by using the parafilm and then it were kept in laboratory condition at $28{ }^{\circ} \mathrm{C}$ and with relative humidity is at $70 \%$. The mortality for each insect were recorded in excel software after $1,3,5$, and 7 days at the same time while the $\mathrm{LC}_{50}$ which is lethal concentration values were analysed by using EPA Probit analysis.

\subsubsection{Insecticide impregnated food method}

The toxicity for each of insecticides which are Cypermethrin, Malathion, Prevathon, Rotenone and also Spinosad was determined by weighting $2.5 \mathrm{~g}$ of rice grains on plastic weight boat by using electrical weighing balance. Then, it was soaked in the solution of insecticides that have been prepared through serial dilution with a different concentration and then it was allowed to evaporate until it fully dried which is about 15 to 20 minutes on the filter paper with $9 \mathrm{~cm}$ in diameter because it easy to identified whether it fully dried or not. After fully dried, the rice grain that have been impregnated with insecticides were placed in vials of ( $30 \mathrm{ml}$ in volume) by using spatula. In order to prevent any incorrect results, the different spatula were used when transferring process into the vials have been made. Then, the same amounts of the rice grain also were soaked with distilled water for the control purpose and have been indicated as $0 \%$ concentration. After rice grains are fully dried, the 10 insects were placed into the vials and the data was collected after 1, 3, 5, and 7 days.

\section{RESULTS}

\subsection{Impregnated filter paper method}

\subsubsection{Toxicity bioassay against adults of sitophilus oryzae via impregnated filter paper method}

The results obtained from impregnated filter paper method showed a significant different between the five concentrations with distilled water. Cypermethrin showed the highest mortality which is $7 \%$ while Rotenone showed the lowest mortality which is $0 \%$ among the insecticides used against the adult of S.oryzae after one day exposure at concentration 0.500 and $0.010 \%$. Cypermethrin was found to be most toxic insecticides with percentage mortality of $100 \%$ followed by Spinosad with a 
percentage mortality of $98.70 \%$ against adult of S.oryzae after 5 days of exposure at the same concentration were $0.500 \%$. There is no significant difference between Rotenone and Malathion on the percentage mortality of $87.50 \%$ and $97.50 \%$, respectively of insect after 5 days of exposure to the insecticides although they were comprised of the different concentrations which are at 0.010 and $0.120 \%$. The lowest percentage of mortality was $40 \%$ obtained from Prevathon insecticides after 5 days of exposure.

Based from result obtained, all the concentrations are no significant difference against Sitophilus oryzae during the 7 days of exposure via filter paper impregnation method. However, the study revealed that the mortality of adult of S.oryzae was increased with the increasing of concentration after 7 days of exposure Table 3. All the insecticides showed no significantly difference at 7 days of exposure except for Cypermethrin at concentration 0.062, 0.031 and $0.125 \%$, respectively, and also Spinosad at concentration $0.031 \%$. Overall, the highest percentage is $100 \%$ of mortality were Cypermethrin while Prevathon showed the less toxic insecticide via filter paper impregnation method compared to other because showed the lowest percentage of mortality which is $96.30 \%$.

Table 3: The toxicity of the tested insecticides against Adult of Sitophilus oryzae via impregnated filter paper method

\begin{tabular}{|c|c|c|c|c|c|}
\hline \multirow{2}{*}{ Treatments } & \multirow{2}{*}{ Concentration (\%) } & \multicolumn{4}{|c|}{ Mortality (\%) } \\
\hline & & Day 1 & Day 3 & Day 5 & Day 7 \\
\hline \multirow{6}{*}{ Cypermethrin } & 0.000 & $0.00 \pm 0.00 \mathrm{~d}$ & $0.00 \pm 0.00 \mathrm{~d}$ & $0.00 \pm 0.00 \mathrm{~d}$ & $0.00 \pm 0.00 \mathrm{~d}$ \\
\hline & 0.031 & $0.25 \pm 0.16 \mathrm{~cd}$ & $1.00 \pm 0.27 \mathrm{~cd}$ & $2.63 \pm 0.26 c$ & $6.00 \pm 0.80 c$ \\
\hline & 0.062 & $0.75 \pm 0.25 \mathrm{~cd}$ & $1.88 \pm 0.29 b c$ & $2.88 \pm 0.39 c$ & $7.40 \pm 0.38 \mathrm{cb}$ \\
\hline & 0.125 & $1.50 \pm 0.27 \mathrm{c}$ & $3.13 \pm 0.40 \mathrm{a}$ & $4.63 \pm 0.78 b$ & $8.50 \pm 0.50 \mathrm{ab}$ \\
\hline & 0.250 & $5.37 \pm 0.59 b$ & $7.00 \pm 0.46 a$ & $8.50 \pm 0.42 a$ & $9.88 \pm 0.13 a$ \\
\hline & 0.500 & $7.00 \pm 0.46 a$ & $8.37 \pm 0.38 \mathrm{a}$ & $10.00 \pm 0.87 \mathrm{a}$ & $10.00 \pm 0.00 a$ \\
\hline \multirow{6}{*}{ Malathion } & 0.000 & $0.00 \pm 0.00 b$ & $0.00 \pm 0.00 b$ & $0.00 \pm 0.00 \mathrm{~d}$ & $0.00 \pm 0.00 b$ \\
\hline & 0.007 & $0.13 \pm 0.13 b$ & $0.38 \pm 0.18 b$ & $6.63 \pm 0.57 c$ & $10.00 \pm 0.00 \mathrm{a}$ \\
\hline & 0.015 & $0.38 \pm 0.18 b$ & $1.13 \pm 0.35 b$ & $7.50 \pm 0.57 b c$ & $10.00 \pm 0.00 \mathrm{a}$ \\
\hline & 0.030 & $0.88 \pm 0.40 b$ & $1.50 \pm 0.28 b$ & $8.50 \pm 0.33 \mathrm{ab}$ & $10.00 \pm 0.00 \mathrm{a}$ \\
\hline & 0.060 & $1.25 \pm 0.37 b$ & $5.25 \pm 0.84 a$ & $9.0 \pm 0.33 \mathrm{ab}$ & $10.00 \pm 0.00 a$ \\
\hline & 0.120 & $4.38 \pm 1.25 a$ & $7.13 \pm 0.69 a$ & $9.75 \pm 0.16 a$ & $10.00 \pm 0.00 a$ \\
\hline \multirow{6}{*}{ Prevathon } & 0.000 & $0.00 \pm 0.00 b$ & $0.00 \pm 0.00 \mathrm{c}$ & $0.00 \pm 0.00 b$ & $0.00 \pm 0.00 b$ \\
\hline & 0.010 & $0.00 \pm 0.00 \mathrm{~b}$ & $0.13 \pm 0.13 b c$ & $3.13 \pm 0.40 \mathrm{a}$ & $8.38 \pm 0.50 \mathrm{a}$ \\
\hline & 0.020 & $0.13 \pm 0.13 \mathrm{ab}$ & $0.38 \pm 0.18 \mathrm{abc}$ & $3.25 \pm 0.41 \mathrm{a}$ & $8.50 \pm 0.42 \mathrm{a}$ \\
\hline & 0.040 & $0.25 \pm 0.13 b$ & $0.63 \pm 0.26 \mathrm{abc}$ & $3.50 \pm 0.42 \mathrm{a}$ & $8.63 \pm 0.60 \mathrm{a}$ \\
\hline & 0.060 & $0.38 \pm 0.18 \mathrm{ab}$ & $0.88 \pm 0.23 \mathrm{ab}$ & $3.88 \pm 0.44 a$ & $9.25 \pm 0.31 \mathrm{a}$ \\
\hline & 0.120 & $0.75 \pm 0.16 a$ & $1.38 \pm 0.26 a$ & $4.00 \pm 0.38 \mathrm{a}$ & $9.63 \pm 0.18 \mathrm{a}$ \\
\hline \multirow{6}{*}{ Rotenone } & 0.000 & $0.00 \pm 0.00 \mathrm{a}$ & $0.00 \pm 0.00 b$ & $0.00 \pm 0.00 b$ & $0.00 \pm 0.00 b$ \\
\hline & 0.0006 & $0.13 \pm 0.13 a$ & $1.00 \pm 0.42 \mathrm{ab}$ & $7.63 \pm 0.42 a$ & $9.63 \pm 0.18 \mathrm{a}$ \\
\hline & 0.001 & $0.00 \pm 0.00 \mathrm{a}$ & $1.38 \pm 0.26 \mathrm{ab}$ & $7.88 \pm 0.48 \mathrm{a}$ & $9.75 \pm 0.16 a$ \\
\hline & 0.002 & $0.13 \pm 0.13 a$ & $1.63 \pm 0.42 \mathrm{a}$ & $8.38 \pm 0.32 \mathrm{a}$ & $10.00 \pm 0.00 a$ \\
\hline & 0.005 & $0.13 \pm 0.13 a$ & $1.88 \pm 0.40 \mathrm{a}$ & $8.50 \pm 0.38 \mathrm{a}$ & $10.00 \pm 0.00 \mathrm{a}$ \\
\hline & 0.010 & $0.00 \pm 0.00 \mathrm{a}$ & $2.25 \pm 0.31 \mathrm{a}$ & $8.75 \pm 0.37 a$ & $10.00 \pm 0.00 a$ \\
\hline \multirow{6}{*}{ Spinosad } & 0.000 & $0.00 \pm 0.00 \mathrm{c}$ & $0.00 \pm 0.00 \mathrm{c}$ & $0.00 \pm 0.00 \mathrm{~d}$ & $0.00 \pm 0.00 \mathrm{c}$ \\
\hline & 0.031 & $0.38 \pm 0.26 c$ & $2.63 \pm 0.26 b$ & $7.00 \pm 0.46 c$ & $7.88 \pm 0.44 b$ \\
\hline & 0.062 & $0.88 \pm 0.30 b c$ & $3.75 \pm 0.37 b$ & $8.50 \pm 0.33 b$ & $9.25 \pm 0.25 \mathrm{a}$ \\
\hline & 0.125 & $1.88 \pm 0.40 \mathrm{ab}$ & $5.25 \pm 0.37 \mathrm{a}$ & $9.00 \pm 0.27 \mathrm{ab}$ & $9.88 \pm 0.13 \mathrm{a}$ \\
\hline & 0.250 & $2.50 \pm 0.50 \mathrm{a}$ & $5.63 \pm 0.46 a$ & $9.25 \pm 0.25 \mathrm{ab}$ & $10.00 \pm 0.00 a$ \\
\hline & 0.500 & $3.25 \pm 0.37 \mathrm{a}$ & $6.63 \pm 0.32 \mathrm{a}$ & $9.88 \pm 0.13 a$ & $10.00 \pm 0.00 \mathrm{a}$ \\
\hline Control & 0 & 0 & 0 & 0 & 0 \\
\hline
\end{tabular}

Values with the same letters in a column are not significantly different $(\mathrm{P}<0.05)$ 


\subsubsection{The $\mathrm{LC}_{50}$ values of tested insecticides against the Sitophilus oryzae adult via impregnated filter paper method}

The $\mathrm{LC}_{50}$ values of each tested insecticides were used to evaluate the toxicity against the adult of Sitophilus oryzae shows in Table 4. Among the tested insecticides, Rotenone showed the highest toxic insecticides with the lowest $\mathrm{LC}_{50}$ values of $\left(0.003 \mu \mathrm{L} / 100 \mathrm{~mL}\right.$ of $\left.\mathrm{H}_{2} \mathrm{O}\right)$ against the adult of S.oryzae via impregnated filter paper method. While, the Prevathon insecticides demonstrated the highest $\mathrm{LC}_{50}$ values of $\left(1.109 \mu \mathrm{L} / 100 \mathrm{~mL}\right.$ of $\left.\mathrm{H}_{2} \mathrm{O}\right)$. Hence, it becomes the less toxic insecticides toward adult of S.oryzae. The other insecticides showed an average in toxicity against the insect were $\left(0.040\right.$ to $0.106 \mu \mathrm{L} / 100 \mathrm{~mL}$ of $\left.\mathrm{H}_{2} \mathrm{O}\right)$. Based on the mortality result, the Rotenone are able to kill half of the population although after 3 days of exposure. In this case, Rotenone showed the lowest value of $\mathrm{LC}_{50}$ because due to the highest percentage of mortality at 7 days of exposure compared to others with the lowest concentration used. As conclusion, based on the $\mathrm{LC}_{50}(0.003$ $\mu \mathrm{L} / 100 \mathrm{~mL}$ of $\mathrm{H}_{2} \mathrm{O}$ ) values the toxicity of the insecticides tested after 7 days of exposure in increasing order were Prevathon $\geq$ Cypermethrin $\geq$ Spinosad $\geq$ Malathion $\geq$ Rotenone via impregnated filter paper method. The mortality of the adult of S.oryzae was affected by the concentration of the tested insecticides. The time exposure also might be the most important role in determining the level of toxicity of the insecticides.

Table 4: The $\mathrm{LC}_{50}$ values of the tested insecticides using impregnated filter paper method against the adult of Sitophilus oryzae

\begin{tabular}{lccccc}
\hline Treatment & $\begin{array}{c}\text { LC } \mathbf{5 0}_{\mathbf{5}}(\boldsymbol{\mu L / 1 0 0 m L} \text { of } \\
\left.\mathbf{H}_{\mathbf{2}} \mathbf{O}\right)\end{array}$ & $\begin{array}{c}\text { Lower } \\
\text { limit }\end{array}$ & $\begin{array}{c}\text { Upper } \\
\text { limit }\end{array}$ & $\begin{array}{c}\text { Chi- } \\
\text { square }\end{array}$ & Slope \\
\hline Cypermethrin $(5.5 \% \mathrm{w} / \mathrm{w})$ & 0.106 & 0.087 & 0.128 & 5.779 & 1.626 \\
Malathion $(84 \% \mathrm{w} / \mathrm{w})$ & 0.017 & 0.010 & 0.025 & 2.269 & 0.778 \\
Prevathon $(5 \% \mathrm{w} / \mathrm{w})$ & 1.109 & $<1.109$ & $>1.109$ & 0.135 & 0.282 \\
Rotenone $(0.1 \% \mathrm{w} / \mathrm{w})$ & 0.003 & $<0.003$ & $>0.003$ & 0.015 & 0.135 \\
Spinosad $(2.5 \% \mathrm{w} / \mathrm{w})$ & 0.040 & 0.013 & 0.068 & 0.498 & 0.646 \\
\hline
\end{tabular}

\subsection{Impregnated food method}

\subsubsection{Toxicity bioassay against adults of Sitophilus oryzae via impregnated food method}

Table 5 shows the comparison between the percentage mortality of S.oryzae on different insecticide concentrations via impregnated food method. The results showed all the insecticides are significant different at 7 days after exposure against the adult. Spinosad showed the highest mortality which is $100 \%$ among the tested insecticides at lowest concentration $(0.010 \%)$ excluding the control while Prevathon and Rotenone, both showed the lowest percentage of mortality against the adult of S.oryzae after 7 days of exposure. The results also showed a significant different at the highest concentration for each of the tested insecticides due the different in dosage that have been used after 7 days of exposure. Spinosad and Prevathon were applied with same concentration but Spinosad showed the highest percentage of mortality with $100 \%$ while Prevathon showed the lowest percentage of mortality in ranges 6.3 to $16.30 \%$ after 7 days of exposure. Besides that, based on the concentration used, percentages of mortality after 7 days of exposure in increasing order were starting with Rotenone $\geq$ Cypermethrin $\geq$ Malathion. Moreover, although Cypermethrin high in concentration used compared to Malathion and Rotenone but Malathion showed the highest percentage of mortality between both insecticides with in ranges of 16.30 to $100 \%$, respectively after 7 days of exposure. Rotenone failed to kill half of the population of the adult of S.oryzae although after 7 days of exposure via food impregnation method.

Overall, mortality adult of Sitophilus oryzae increased with the increasing the concentration of the insecticides and all the concentration were differed significantly compared with the control at 7 days after exposure. As conclusion, based on the percentage of mortality, Spinosad insecticides was 
the most effectives insecticides via food impregnation method compared to other because it competent to kill half of the population of the adult as early one day after exposure.

Table 5: The Toxicity of the tested insecticides against Sitophilus oryzae by using the impregnated food method

\begin{tabular}{|c|c|c|c|c|c|}
\hline \multirow[t]{2}{*}{ Treatment } & \multirow[t]{2}{*}{ Dosage (\%) } & \multicolumn{4}{|c|}{ Mortality (\%) } \\
\hline & & Day 1 & Day 3 & Day 5 & Day 7 \\
\hline \multirow{6}{*}{ Cypermethrin } & 0.000 & $0.00 \pm 0.00 b$ & $0.00 \pm 0.00 \mathrm{~d}$ & $0.00 \pm 0.00 \mathrm{~d}$ & $0.00 \pm 0.00 \mathrm{~d}$ \\
\hline & 0.008 & $0.00 \pm 0.00 b$ & $0.25 \pm 0.16 \mathrm{~d}$ & $1.63 \pm 0.46 \mathrm{~cd}$ & $2.25 \pm 0.41 c$ \\
\hline & 0.015 & $0.13 \pm 0.13 b$ & $1.00 \pm 0.33 c$ & $2.88 \pm 0.35 c$ & $5.38 \pm 0.65 b$ \\
\hline & 0.031 & $0.00 \pm 0.00 b$ & $2.13 \pm 0.40 c$ & $7.13 \pm 0.74 b$ & $8.50 \pm 0.378 a$ \\
\hline & 0.062 & $0.75 \pm 0.31 \mathrm{ab}$ & $4.75 \pm 0.45 b$ & $8.50 \pm 0.38 \mathrm{ab}$ & $9.38 \pm 0.26 a$ \\
\hline & 0.125 & $1.75 \pm 0.62 \mathrm{a}$ & $6.38 \pm 0.50 \mathrm{a}$ & $9.13 \pm 0.30 \mathrm{a}$ & $9.38 \pm 0.26 a$ \\
\hline \multirow{6}{*}{ Malathion } & 0.000 & $0.00 \pm 0.00 b$ & $0.00 \pm 0.00 c$ & $0.00 \pm 0.00 \mathrm{~d}$ & $0.00 \pm 0.00 \mathrm{e}$ \\
\hline & 0.00015 & $0.13 \pm 0.13 b$ & $0.25 \pm 0.16 b c$ & $0.63 \pm 0.18 c d$ & $1.25 \pm 0.37 \mathrm{de}$ \\
\hline & 0.0003 & $0.38 \pm 0.18 b$ & $0.63 \pm 0.26 b c$ & $1.13 \pm 0.23 \mathrm{~cd}$ & $2.63 \pm 0.57 \mathrm{~cd}$ \\
\hline & 0.0006 & $0.50 \pm 0.19 b$ & $0.88 \pm 0.30 b c$ & $1.50 \pm 0.50 c$ & $4.00 \pm 0.42 b c$ \\
\hline & 0.0012 & $0.75 \pm 0.25 b$ & $1.88 \pm 0.40 b$ & $4.25 \pm 0.49 b$ & $5.00 \pm 0.54 b$ \\
\hline & 0.012 & $5.75 \pm 0.88 a$ & $6.25 \pm 0.81 \mathrm{a}$ & $9.38 \pm 0.40 \mathrm{a}$ & $10.00 \pm 0.00 \mathrm{a}$ \\
\hline \multirow{6}{*}{ Prevathon } & 0.000 & $0.00 \pm 0.00 b$ & $0.00 \pm 0.00 c$ & $0.00 \pm 0.00 b$ & $0.00 \pm 0.00 b$ \\
\hline & 0.010 & $0.00 \pm 0.00 b$ & $0.13 \pm 0.13 b c$ & $0.38 \pm 0.26 b$ & $0.63 \pm 0.26 a b$ \\
\hline & 0.020 & $0.13 \pm 0.12 \mathrm{ab}$ & $0.25 \pm 0.16 b c$ & $0.50 \pm 0.27 b$ & $0.63 \pm 0.26 \mathrm{ab}$ \\
\hline & 0.040 & $0.25 \pm 0.16 \mathrm{ab}$ & $0.50 \pm 0.20 \mathrm{abc}$ & $0.63 \pm 0.18 \mathrm{ab}$ & $0.88 \pm 0.23 \mathrm{ab}$ \\
\hline & 0.060 & $0.38 \pm 0.18 \mathrm{ab}$ & $0.75 \pm 0.16 \mathrm{ab}$ & $0.88 \pm 0.23 \mathrm{ab}$ & $1.13 \pm 0.23 a$ \\
\hline & 0.120 & $0.75 \pm 0.25 a$ & $1.13 \pm 0.23 a$ & $1.50 \pm 0.33 a$ & $1.63 \pm 0.38 \mathrm{a}$ \\
\hline \multirow{6}{*}{ Rotenone } & 0.000 & $0.00 \pm 0.00 \mathrm{a}$ & $0.00 \pm 0.00 \mathrm{a}$ & $0.00 \pm 0.00 b$ & $0.00 \pm 0.00 c$ \\
\hline & 0.00063 & $0.00 \pm 0.00 \mathrm{a}$ & $0.25 \pm 0.16 a$ & $0.13 \pm 0.13 b$ & $0.25 \pm 0.16 c$ \\
\hline & 0.00125 & $0.13 \pm 0.13 a$ & $0.13 \pm 0.13 a$ & $0.38 \pm 0.18 \mathrm{ab}$ & $0.50 \pm 0.19 b c$ \\
\hline & 0.0025 & $0.13 \pm 0.13 a$ & $0.25 \pm 0.16 a$ & $0.63 \pm 0.18 \mathrm{ab}$ & $0.88 \pm 0.30 \mathrm{abc}$ \\
\hline & 0.005 & $0.13 \pm 0.13 a$ & $0.25 \pm 0.16 a$ & $0.75 \pm 0.25 \mathrm{ab}$ & $1.25 \pm 0.25 \mathrm{ab}$ \\
\hline & 0.010 & $0.25 \pm 0.25 a$ & $0.38 \pm 0.26 a$ & $1.00 \pm 0.28 \mathrm{a}$ & $1.63 \pm 0.26 a$ \\
\hline \multirow{6}{*}{ Spinosad } & 0.000 & $0.00 \pm 0.00 b$ & $0.00 \pm 0.00 \mathrm{~d}$ & $0.00 \pm 0.00 c$ & $0.00 \pm 0.00 b$ \\
\hline & 0.010 & $1.00 \pm 0.39 b$ & $6.75 \pm 0.62 c$ & $9.63 \pm 0.18 b$ & $10.00 \pm 0.00 \mathrm{a}$ \\
\hline & 0.020 & $4.63 \pm 1.21 \mathrm{a}$ & $6.88 \pm 0.61 b c$ & $10.00 \pm 0.00 \mathrm{a}$ & $10.00 \pm 0.00 \mathrm{a}$ \\
\hline & 0.040 & $5.38 \pm 0.53 a$ & $8.00 \pm 0.42 \mathrm{abc}$ & $10.00 \pm 0.00 \mathrm{a}$ & $10.00 \pm 0.00 \mathrm{a}$ \\
\hline & 0.080 & $6.38 \pm 0.63 a$ & $8.63 \pm 0.26 a b$ & $10.00 \pm 0.00 \mathrm{a}$ & $10.00 \pm 0.00 \mathrm{a}$ \\
\hline & 0.120 & $5.50 \pm 0.50 a$ & $9.38 \pm 0.324 \mathrm{a}$ & $10.00 \pm 0.00 \mathrm{a}$ & $10.00 \pm 0.00 \mathrm{a}$ \\
\hline Control & 0 & 0 & 0 & 0 & 0 \\
\hline
\end{tabular}

Values with the same letters in a column are not significantly different $(\mathrm{P}<0.05)$

\subsubsection{The LC $\mathrm{C}_{50}$ values of tested insecticides against the Sitophilus oryzae adult via impregnated food method}

The $\mathrm{LC}_{50}$ values of the tested insecticides at different concentration were used to evaluate the mortality of rice weevil as shown in Table 6. Among the tested insecticides it was observed that Spinosad was the most toxic insecticides with the lowest $\mathrm{LC}_{50}$ value of $0.001 \%$ compared to other insecticides. Hence, it could provide the strong toxicity on the insect compared to Prevathon were showed the lowest toxic against the adult of S.oryzae with $\mathrm{LC}_{50}$ values of $5.776 \%$. The other insecticides showed a moderated toxicity against the adult of S.oryzae with $\mathrm{LC}_{50}$ values of 0.003 , 0.050 and $0.875 \%$, respectively. Overall, all the insecticides showed significant higher control against adult of S.oryzae via food impregnation method except for Prevathon insecticides. Based on the $\mathrm{LC}_{50}$ values, it can be conclude that the toxicity of the tested insecticides after 7 days of exposure in increasing order were Prevathon $\geq$ Rotenone $\geq$ Cypermethrin $\geq$ Malathion $\geq$ Spinosad. 
Table 6: The $\mathrm{LC}_{50}$ values of the tested insecticides using food impregnation method against the adult of Sitophilus oryzae

\begin{tabular}{lccccc}
\hline Treatment & $\begin{array}{c}\mathbf{L C}_{\mathbf{5 0}}(\boldsymbol{\mu} \mathbf{L} / \mathbf{1 0 0} \mathbf{m L} \\
\left.\text { of } \mathbf{H}_{\mathbf{2}} \mathbf{O}\right)\end{array}$ & $\begin{array}{c}\text { Lower } \\
\text { limit }\end{array}$ & $\begin{array}{c}\text { Upper } \\
\text { limit }\end{array}$ & $\begin{array}{c}\text { Chi- } \\
\text { square }\end{array}$ & Slope \\
\hline Cypermethrin $(5.5 \% \mathrm{w} / \mathrm{w})$ & 0.050 & 0.040 & 0.064 & 3.220 & 1.402 \\
Malathion $(84 \% \mathrm{w} / \mathrm{w})$ & 0.003 & 0.002 & 0.004 & 0.661 & 1.238 \\
Prevathon $(5 \% \mathrm{w} / \mathrm{w})$ & 5.776 & $<0.719$ & $>0.719$ & 0.368 & 0.720 \\
Rotenone $(0.1 \% \mathrm{w} / \mathrm{w})$ & 0.875 & $<0.073$ & $>0.073$ & 0.242 & 0.683 \\
Spinosad $(2.5 \% \mathrm{w} / \mathrm{w})$ & 0.001 & 0.000 & 0.003 & 1.106 & 0.579 \\
\hline
\end{tabular}

\section{DISCUSSION}

In this study, different toxicity level for five types of insecticides against the adults of S.oryzae was determined. Besides that, each of the insecticides was applied for six different concentration based on the dosage recommendation from previous study including control that have been done in the laboratory condition. Hence, all the toxicities for each of the tested insecticide which are Cypermethrin, Malathion, Prevathon, Rotenone and also Spinosad showed a various level of toxicities in this experiment after 7 days of exposure. So that, some of the insecticides are able to kill the adults of S.oryzae in a short time when tested in the laboratory bioassay while some of them showed a slower mortality rate within the time of exposure. Among of them, some of the insecticides that have been tested showed a less toxic to the adult of S.oryzae. Since, the purpose in this study is to identify the effectiveness of the insecticides against the adult of Sitophilus oryzae, hence we able to identify the purpose in this study.

In the present study, after one day of exposure to the insecticides by using the filter paper bioassay, it was found that the rotenone gave the lowest value of mortality compared to the other four insecticides tested against adult of $S$. oryzae while the highest mortality for day one was cypermethrin. Since rotenone showed the lowest mortality for day one, hence it become less toxic to the $S$. oryzae. Next, the result for days three and five showed prevathon was the lowest mortality compared to others four insecticides while the highest still cypermethrin. Second highest in toxicity was rotenone. This was similarly with other plant study auch as Nukenine et al. (2011) reported that maximum mortality of $98.8 \%$ was achieved to adult $S$. zeamais with neemazal at a concentration of $12 \mathrm{~g} / \mathrm{kg}$ seed after 14 days of treatment and greatly reduced early progeny emergence. However, after days seven of exposure to insecticides the highest mortality was Malathion and the lowest was prevathon. For instance, study by Chintzoglou et al., (2008) for $L$. bostrychophila, chlorantraniliprole which is active ingredient for prevathon showed less effective in maize and whole rice than in barley, oats, peeled rice and wheat. This might due to the mode of action which is stomach and contact.

The mode of action also played an important role in increasing the mortality of the adult of $S$. oryzae in order to give a faster knock down when the insect fed the rice grains (Adeyemi, 2010). The concentrations used and the mode of action of insects played an important role in this experiment as indicate the toxicity of the insecticides (Kavallieratos et al., 2011). This can be proved by Iqbal et al., (2012), Malathion as a highly active insecticide to adult of S. oryzae that could be due to differences in the application of pesticide and environmental conditions. When organisms were treated with the insecticides, continuous nerve impulse transmission due to inhibition of acetylcholine esterase may in turn result sudden death of organisms. Generally, in this present study, all of the insecticides that have been tested able to control the adults of $S$. oryzae although their toxicities is different because some of insecticides might need a high dose in order to kill the adult at a fixed time. In order to get the same level of toxicities, the concentration of the insecticides need to be increase. So that it able to have a high level of toxicities in this experiment. 
As conclusion, for the contact toxicity by using impregnated filter paper method showed the most effective's insecticides was Malathion insecticide compared to prevathon because able to kill $100 \%$ adult of $S$. oryzae after seven days of exposure and gave the highest percentage mortality of $S$. oryzae. However this concentration could be increase in order to get a better mortality of the insect. Classification of the insecticides also important in identify the toxicity of the insecticides. Besides that, concentration of the insecticides was played an important role in increasing the mortality of the rice weevils. The higher mortality might happened due to the classification and type of the insecticides used itself with different concentration also become an important factors in increasing the mortality of the insect (Kljajic et al., 2004).

Next, based on the second method in evaluating the toxicity of the tested insecticides against adult of $S$. oryzae was via impregnated food method. In present study, the result showed that the lowest mortality was rotenone after one day of exposure while the highest mortality was Malathion. However, after three, five and seven days of exposure to insecticides results showed the highest percentage of mortality was spinosad while rotenone remain the same which is the lowest percentage of mortality against adult of $S$. oryzae. Means, it showed that rotenone was the lowest toxicity against adult of $S$. oryzae compared to prevathon, cypermethrin, Malathion and spinosad. Hence, spinosad was the most toxic compared to rotenone and very effectives in controlling the adult of $S$. oryzae. It can kill the insect with a short period of time. The efficacy of spinosad in the present investigation was in tune with the findings of Subramanyam et al., (2006) who reported mortality of more than $98 \%$ within 12 days when seed was treated with spinosad 1 or $2 \mathrm{mg} / \mathrm{kg}$. Based on Sparks et al., (2001), the Spinosad insecticides might need a minimum time in order to cause $50 \%$ mortality as it very toxic to insects because its action on the nervous system was at nicotine acetylcholine and also at gamma-aminobutric acid (GABA) receptor sites, so that it very effectives by ingestion and also contact.

In impregnated food method, the results showed that Rotenone less toxic compared to spinosad against adult of $S$. oryzae because lowest in percentage of mortality and the concentration used in this experiment were unable to kill half of the population adult of $S$. oryzae efficiently as in impregnated filter paper method. We can conclude that, the Rotenone was less effectives in controlling the adult of $S$. oryzae as in impregnated filter paper method because it easily evaporated and only effectives if the insecticides were prepared not more than one week (Norhayu, 2015). Rotenone was botanical insecticides and become more effective if the solutions was freshly prepared. Botanical insecticides have been designed to be more stable in the environment, safe to human being and also provide longer lasting control for the insect pests. A variety of responses have been reported from toxicological studies against S.oryzae by several toxicologist viz. essential oil, oil from eucalyptus, terpenes and benzaldehyde, neem extract $\mathrm{RB}-\mathrm{a}$ in comparison with pyrethroids (Azmi et al., 1998). Similarly in this study, the results showed a different response for Rotenone and other four insecticides.

Besides that, Cypermethrin and Malathion insecticides also can be used for controlling the adult of $S$. oryzae efficiently because high in percentage of mortality after seven days of exposure. Although these insecticides are less toxic compared to the Spinosad, the results showed that both of them also intermediate in toxicity against the adult of $S$. oryzae via this method. Hence, based on the previous study, it state that the class of the Cypermethrin was in class II while the Malathion insecticides was in class III. The findings on mortality of adult of S. oryzae by Parimala and Maheswari (2011) increased marginally at 48 hours after exposure as increased in this present study. Besides that, their mode of action is similar which is stomach and contact. Mode of action is very important in order to know whether these species such as insect pests, fish, bird and mammals can be effects by the insecticides. Pesticide kills or inactive a pests can be identify through the mode of action. Insecticides can be classified based on this mode of action because each pest will have a different level of toxicity for each insecticide. In this study, the mode of action for contact dermal is through the skin of insects while for the stomach oral is through the mouth. 
However, in this method, after spinosad, Malathion showed the second highest percentage of mortality compared to cypermethrin. Since, cypermethrin give more effective and show toxicity to wide range of insect's pest belonging to different orders other than coleopteran compared to other pyrethroids (Rani, 1997). (Ahsan et al., 2005) stated that the Cypermethrin were effectives against S. oryzae where $\mathrm{LC}_{90}$ found to be at $19 \mathrm{mug} / \mathrm{cm}^{2}$. Thaung et al. (1986) reported that, the mortality of $S$. oryzae in wheat and maize when the temperature and insecticides where joint together and toxicity of cypermethrin decreased with increasing temperature. Although this present study was done in laboratory condition but the temperature was not the main factor. This can be prove in some studied, Rashid (2012) examined that temperature was controlled within a large incubator where aeration was also not a killing factor toward toxicity of cypermethrin and Malathion. Thus, the data observed solely the effects of the insecticides itself. Hence, Malathion and Spinosad insecticides much efficiently for controlling the populations of adult of $S$. oryzae.

Generally, the type chemical class of Malathion and Spinosad are from Organophosphorus and Spinosad respectively. In addition, the class of toxicity for both insecticides was located at class III and IV, their mode of action is similar which is by contact and stomach action but Spinosad insecticides revealed more unique in mode of action Srinivas et al. (2003), compared to Malathion insecticides against the stored-product pests compared to other known insecticides (Thompson et al., 2000). As conclusion, spinosad was the most effectiveness insecticide in controlling the adults of $S$. oryzae via impregnated food method because give the highest percentage of mortality as early five days of exposure.

In most studies, insecticides impact has been evaluated by exposure of the insect pest to a range pesticide concentration (Stark and Wennergren, 1995). Evaluation of insecticides toxicity may determine by the percentages of insect dead at the fixed time $\left(\mathrm{LC}_{50}\right)$. The different insecticides may show the different toxicity against insect pest. A highly toxic insecticides applied at a low concentration in the laboratory may cause high mortality compared to less toxic insecticides used at a higher concentration. In this case, it become more useful to compare the relative toxicity of insecticides against insect pest by measuring the $\mathrm{LC}_{50}$ while for the antifeedant activity of the insect that have been tested it become easier to identify by using the feeding deterrent index. In the present study, the toxicity of the tested insecticides was identified based on the values of $\mathrm{LC}_{50}$ against the adult of $S$. oryzae.

Starting with the impregnated filter paper method, prevathon showed the highest value of $\mathrm{LC}_{50}$ while the lowest was rotenone. In this case, prevathon gave highest value of $\mathrm{LC}_{50}$ it means that prevathon is the less toxic insecticide among the others because the highest values of $\mathrm{LC}_{50}$, the less toxic insecticide and vice versa. Hence, rotenone with lowest value of $\mathrm{LC}_{50}$ become more toxic compared to Prevathon and it able to control and prevent the adult of S.oryzae from destruct the rice grain. Among the insecticides tested, Rotenone with the lowest value of $\mathrm{LC}_{50}$ able to reduce the $\mathrm{F}_{1}$ progeny of S.oryzae might due to the types of the insecticides itself (McGovern, 1977). (Rajasekaran and Kumaraswami, 1985) reported that grains coated with plant extracts completely inhibited the development of insect like $S$. oryzae. Plant derivatives also reduce the survival rates of larvae and pupae and adult emergence (Koul et al., 2008). Development of eggs and immature stages inside grain kernel were also inhibited by plant derivatives (Boeke et al., 2004). The crude extract also retarded development and caused mortality of larvae, cuticle melanisation, and high mortality in adults (Jamil et al., 1984). Besides that, although Malathion showed the second highest toxic after rotenone based on the $\mathrm{LC}_{50}$ but Malathion still can be categorised as high in toxicity and they are able to control the adult population on S.oryzae due to higher concentration used compared to Rotenone. Rotenone become more toxic than malathion because Champ et al. (1969) established that, the Malathion insecticides was only gave effective results when applied to the larvae of the $S$. oryzae not to the adult stage. Lasota and Dybas (1996) stated that Malathion was the next best chemical in reducing $S$. zeamais population. Different with previous findings that, Malathion was less effective against $S$. zeamais by Pathak and Jha (1999) with $\mathrm{LC}_{50}$ value of $4.913 \mathrm{ppm}$. However, 
it highly active insecticide against adult could due to the differences in the application of pesticide and environment condition such as in air, malathion have been reported by Howard (1991) that sunlight able to broke down this type of insecticide easily approximately one and one-half days only because the solutions used is very quick to degrade. The sudden death of the insects occurs when it have been treated to the insecticides because the reaction with the continuous nerve impulse transmission due to inhibition of acetycholine esterase inside insect body. As conclusion, rotenone the most effectives against the adult of $S$. oryzae via impregnated filter paper method based on $\mathrm{LC}_{50}$ value in the laboratory condition.

As mentioned above for impregnated filter paper method, the highest values of $\mathrm{LC}_{50}$, means the less toxic insecticides towards adult of $S$. oryzae while the lowest values of $\mathrm{LC}_{50}$, the more toxic insecticides against insect. Similarly concept used in this present study via impregnated food method, the result showed lowest toxicity was prevathon while the highest toxicity was spinosad. The classification of insecticides played important role between this two insecticides because it showed a different in toxicity based on $\mathrm{LC}_{50}$ (Cordova et al., 2006). The class of toxicity for prevathon was located at class II and it a novel insecticide belonging to the chemical group of anthranilic diamides (Lahm et al., 2005) while spinosad was in class IV. The application of prevathon formulations reduced offspring emergence in comparison with the controls, however with adult suppression was not achieved, even at $10 \mathrm{mg}$ chlorantraniliprole $\mathrm{kg}^{-1}$ grain, with the exception of maize (Kavallieratos et al., 2013). Fang et al. (2002) reported that mortality of $R$. dominica and $S$. oryzae in wheat treated with spinosad at $1 \mathrm{mg}$ spinosad $\mathrm{kg}^{-1}$ grain was $100 \%$ after 7 days of exposure, but at the same conditions, mortality was low for T. castaneum. Hence, spinosad showed the most effectives insecticide for controlling the adult of $S$. oryzae compared to prevathon via impregnated food method.

In this study, Malathion showed the second highest toxicity compared to spinosad based on the value of $\mathrm{LC}_{50}$ against adult of $S$. oryzae via impregnated food method. Malathion are less effectives because the wide used of this types of insecticides gave the resistance to the stored product pests including $S$. oryzae although the concentration used were higher than spinosad. However, Champ et al. (1969) established that malathion was effective only against newly hatched larvae of $S$. oryzae, but previous study represents by Iqbal et al. (2012) malathion as a highly active insecticide as similarly in this study against the adult that could be due to differences in the application of pesticide and environmental conditions. When organisms were treated with the insecticides, continuous nerve impulse transmission due to inhibition of acetylcholine esterase may in turn result sudden death of organisms.

On the other hand, it was found that Rotenone showed a less toxic against the adult of S. oryzae via impregnated food method compared to spinosad. This have been concluded by Rani et al. (1997) pyrethroids which is synthetic product give more mortality towards insect rather than plant extract due to the dilution of the crude extract of plant only produced a very little its actual active ingredient as compared to the pure synthetic compounds. As reported in previous studies by Dyck et al. (1985) synthetic compounds such as pyrethroids and Cypermethrin gave the differences in biocidal activities between the plant extract due to the immediate neurotoxic effect of synthetic products on insect's pests. The toxicity have been identified as small values of $\mathrm{LC}_{50}$, the more toxic insecticides toward the adult of $S$. oryzae and it becomes more effective to control the insects storage-pest. Overall, for both methods, Spinosad and Malathion is more toxic than prevathon as showed in this present study.

As conclusion, Spinosad were found to have a strong repellence and feeding effect on the adult of S. oryzae. According to McGovern (1977) stated that all the compounds will considered as repellents if the compounds was in the class IV. In this study, repellency and deterrency decrease with increase in concentration and period of time and the result showed a decreasing in relative growth rate and also weight loss in this experiment. Among the tested insecticides, Spinosad 
exhibited more repellency and deterrency followed by Malathion, Cypermethrin, Prevathon, and last is Rotenone which showed the least effective toward adult of $S$. oryzae in this experiment. In this case, Spinosad can be identified as the most effective insecticides in controlling the insect pests on a several crops (Thompson et al., 1997) because it has metabolite in the soil which is actinomycete bacterium, Sacchoropolyspore spinosa. Besides that, Spinosad have been proved that it provides good services in the crop protection because able to control the adult of $S$. oryzae in both method especially when they were works together with synthetic products. Moreover, Spinosad gave much effective among the others insecticides because it have a novel molecular structure and it mode of action is very suitable in this study as they acting on the insect nervous system at the nicotic acetylcholine and gamma-aminobutyric acid (GABA) receptor sites. Hence, is become very toxic to the insects by ingestion or contact bioassays (Sparks et al., 2001). Generally, most of the worldwide studies have verified that Spinosad have many advantages in controlling the crops such as ornamentals, vegetables, cotton and also turf to control the pests in liquid state and become very effective insecticides (Bret et al., 1997). This have been supported by Saunders and Bret (1997) by stated that it meets requirements for less human risk and eco-friendly.

Besides that, Spinosad also very good for insecticide resistance management (Salgado, 1997). In order for controlling the stored products Spinosad is very considerable efficacy against this types of pests (Toews and Subramanyam, 2003). In this study, Spinosad are able to control the adult of $S$. oryzae at dosage of concentration as $0.12000 \%$ are suitable dosage in controlling this insect. In our study showed that at all concentrations, Spinosad was able to kill half of adult of $S$. oryzae as early as one day after the exposure and killed all the adults after seven days of exposure. However, Athanassiou et al. (2008) and Vayias et al. (2009) found that Spinosad insecticides gave a lower mortality and less effective toward maize grain compared to the rice grain and barley. Similar observations have been reported by studies elsewhere (Nayak et al., 2005; Athanassiou et al., 2008) on the T.castaneum showed that their findings is highly tolerant to Spinosad and that high survival rate was observed at double dose of $1.4 \mathrm{ppm}$. As conclusion, the Spinosad is very effective towards adult of $S$. oryzae in both bioassays which is in impregnated filter paper and food method that have been study in this experiment.

\section{CONCLUSION}

The conclusion in this study from the toxicity bioassay and the antifeedant activity against adult of the Sitophilus oryzae was observed. In contact toxicity by using the filter paper impregnation method showed that Rotenone gave the highest value of $\mathrm{LC}_{50}$ which is $0.003 \mu \mathrm{L} / 100 \mathrm{~mL}$ of $\mathrm{H}_{2} \mathrm{O}$, hence it gave the highest mortality rate compared to other insecticides in this experiment. The effective concentration for this insecticides was at $0.010 \%$ because it able to kill the insect within 7 days of exposure. Hence, it can be suggested the most effective dosage for controlling the adult of S. oryzae in the laboratory condition. Besides that, it showed a significant different among all the insecticides compared to the control concentration which is by using the distilled water. In this case, can conclude that, the distilled water will not affected the adult of the $S$. oryzae because after the observation that have been made, there was no mortality have been recorded within 7 days of exposure.

Besides that, for the toxicity by using the food impregnation method, the result showed that the lowest value of $\mathrm{LC}_{50}$ was Spinosad and Malathion insecticides. Means that, both of the insecticides gave the highest mortality rates compared to other insecticides in this experiment. The effective dosage for both insecticides was at concentration $0.12 \%$. Then, results for the $\mathrm{LC}_{50}$ values from food impregnation method were carried out for further study of antifeedant activity in order to evaluate the feeding deterrence index against adult of the S.oryzae. The result showed that feeding deterrence index were significantly different among all the insecticides tested. Therefore, Spinosad showed the most effective at concentration $0.12 \%$ for controlling adult of S.oryzae and the advantages of using this type of insecticides was it give low environmental and human risk. Hence, 
all the rice industries could prevent their stored products against the adult of S.oryzae and able to reduce the qualitative and quantitative losses.

\section{RECOMMENDATIONS}

By knowing the best dosage and the antifeedant activity it may increase the level of effectiveness of the insecticides use. However, further research should be encouraged to standardise the dosage and the modes of action for the type of insect uses. Besides that, it also could possibly be produced in the industries for easier accessibility to farmer and store keepers. These will help to encourage wider adoption and use, avoid wastage and encourage greater economy of use. However, the plantbased bio-pesticides also recommended in the future study because it will keep our environment safe and gives less harmful to human, also it will avoid resistant of the insects towards pesticides. Thus, rice industry able to reduce the losses caused by the storage pests especially $S$. oryzae. Lastly, in the future study, preparation and handling of the insecticides should be more caution and precise in order to prevent from any error or inaccurate data collection. Safety rules also need to be applied while undergo the experiment.

Funding: This study received no specific financial support.

Competing Interests: The authors declared that they have no conflict of interests.

Contributors/Acknowledgement: All authors participated equally in designing and estimation of current research.

Views and opinions expressed in this study are the views and opinions of the authors, Asian Journal of Agriculture and Rural Development shall not be responsible or answerable for any loss, damage or liability etc. caused in relation to/arising out of the use of the content.

\section{References}

Adedire, C. O., \& Lajide L. (2003). Ability of extracts of ten tropical plant species to protect maize grains against infestation by the maize weevil, Sitophilus zeamais during storage. Nigeria Journal of Experimental Biology, 4, 175-179.

Adeyemi, M. H. (2010). The potential of secondary metabolites in plant material as deterrents against insect pests: A review. African Journal of Pure and Applied Chemistry, 4, 243-246.

Agro-economic. (2007). Statistic agriculture in Thailand 2007. Department of Agriculture BKK, Thailand.

Ahsan, T., Ahmad, I., Yasmeen, N., Tabassum, R., Azmi, A., \& Shoaib, M. (2005). Effects of Acorus calamus extract and cypermethrin on enzymatic activities in Sitophilus oryzae. Journal Experimental Zoology India, 3(2), 169-173.

Athanassiou, C. G., Kavallieratos, N. G., Yiatilis, A. E., Vayias, B. J., Mavrotas, C. S., \& Tomanovic, Z. (2008). Influence of temperature and humidity on the efficacy of spinosad against four stored grain beetle species. Journal of Insect Sciences, 8(60), 1-9. doi.org/10.1673/031.008.6001.

Azmi, M. A., Hasan, S. N., Khan, M. F., \& Akhtar, K. (1998). Toxicity of Cypermethrin and Malathion on Rice Weevil Sitophilus oryzae (L.) and Their Effect on Esterase Isozymes. Journal of Chemical, Biological and Physical Sciences, 3(1), 304-313.

Beckett, S. J., Longstaff, B. C., \& Evans, D. E. (1994). A comparison of the demography of four major stored grain coleopteran pest species and its implications for pest management. Proceedings of the Sixth International Working Conference on Stored-Product Protection, pp. 491-497. CAB International, Wallingford, UK.

Boeke, S. J., Baumgart, I. R., Van Loon, J. J., Van Huis, A. A., Dicke, M., \& Kossou, D. K. (2004). Toxicity and repellence of African plants traditionally used for the protection of stored cowpea against Callosobruchus maculatus. Journal of Stored Products Research, 40(4), 423-438. doi.org/10.1016/s0022-474x(03)00046-8. 
Bret, B. L., Larson, L. L., Schoonover, J. R., Sparks, T. C., \& Thompson, G. D. (1997). Biological properties of spinosad. Down to Earth, 52(1), 6-13.

Campbell, J.F. (2008). Evaluating sources of stored-product insect infestation. pp. 137-157.

Champ, B. R., Steele, R. W., Genn, B. G., \& Elms, K. D. (1969). A comparison of Malathion, diazinon, fenitrothion and dichlorvos for control of (L) and Rhizopertha dominica (F) in wheat. J. Stored Products Res., 5, 21-48.

Chen, C. (2003). Evaluation of air oven moisture content determination methods for rough rice. Bio-systems Engineering, 86, 447-457.

Chintzoglou, G. J., Athanassiou, C. G., Markoglou, A. N., \& Kavallieratos, N. G. (2008). Influence of commodity on the effect of spinosad dust against Rhyzopertha dominica (F.) (Coleoptera: Bostrychidae) and Sitophilus oryzae (L.) (Coleoptera: Curculionidae). International Journal of Pest Management, 54, 277-285.

Cordova, D., Benner, E. A., Sacher, M. D., Rauh, J. J., Sopa, J. S., \& Lahm, G. P. (2006). Anthranilic diamides: a new class of insecticides with a novel mode of action, ryanodine receptor activation. Pesticide Biochemistry and Physiology, 84, 196-214. doi.org/10.1016/j.pestbp.2005.07.005.

Dyck, P. J., Masatake, S., Gerald, P. S., Alfred, C. L., Karen, F. O., \& Margaret, F. S. (1985). The evaluation of a new synthetic pyrethroids Pesticide (Permethrin) for neurotoxicity. Journal of Environmental Pathology, Toxicology, and Oncology, 5, 109-118.

Fang, L., Subramanyam, B., \& Arthur, F. H. (2002). Effectiveness of spinosad on four classes of wheat against five stored product insects. Journal of Economic Entomology, 95, 640-650.

Haque, M. A., Nakakita, H., Ikenaga, H., \& Sota, N. (2000). Development inhibiting activity of some tropical plants against Sitophilus zeamais Motschulsky (Coleoptera: Curculionidae). Journal of Stored Products Research, 36, 281-287.

Howard, P. H. (1991). Handbook of environmental fate and exposure data for organic chemicals Volume 3. Lewis Publishers. Chelsea Michigan.

Huang, F., \& Subramanyam, B. (2005). Management of five stored product insects in wheat with pirimiphosmethyl and pirimiphosmethyl plus synergized pyrethrins. Pest Management Science, 61, 356-362.

Huang, Y., \& Ho, S. H. (1998). Toxicity and antifeedant activities of cinnamaldehyde against the grain storage insects, Tribolium castaneum (Herbst) and Sitophilus zeamais Motsch. Journal of Stored Products Research, 34, 11-17.

Iqbal, M. H., Rashid, M. A., Rowshan, A. B., \& Reza, M. S. (2012). Toxicity of Cypermethrin and Malathion on Rice Weevil Sitophilus oryzae (L.) and Their Effect on Esterase Isozymes. Journal of Chemical, Biological and Physical Sciences, 3(1), 305-313.

IRRI (2004). World Rice Statistics. Retrieved from: http://www.irri.org/index.php? Option= com_k2 and view $=$ item list and layout $=$ category and task $=$ category and id $=744$ and Item id $=100346$ and Lang $=$ en.

Jamil, K., Rani, U., \& Thyagarajan, G. (1984). Water hyacinth-apotential new juvenile hormone mimic. International Pest Control, 26(4), 106-108, 1984.

Kavallieratos, N. G., Athanassiou, C. G., \& Boukouvala, M. C. (2013). Insecticidal effect of chlorantraniliprole against major stored-product insect pests in different grain commodities under laboratory tests. Pest Management Science, 69, 1141-1154.

Kavallieratos, N. G., Athanassiou, C. G., Hatzikonstantinou, A. N., \& Kavallieratou, H. N. (2011). Abiotic and biotic factors affect efficacy of chlorfenapyr for control of stored-product insect pests. Journal of Food Protection, 74, 1288-1299.

Kljajic, P., Andric, G., \& Peric, I. (2004). Effects of several contact insecticides on adults of three Sitophilus species. Proceedings of the $9^{\text {th }}$ International Working Conference on StoredProduct Protection, 15-18 October, ABRAPOS, Passo Fundo, RS, Brazil.338-343.

Koul, O. S., Walia, \& Dhaliwal, G. S. (2008). Essential oils as green pesticides: potential and constraints. Biopesticide International, 4(1), 63-88. 
Kucerova, Z. R., Aulicky, V., \& Stejskal. (2003). Accumulation of pest arthropods in grain residues found in an empty store. Journal of Plant Diseases and Protection, 110, 499-504. doi.org/10.1007/bf03356127.

Lahm, G. P., Selby, T. P., Freudenberger, J. H., Stevenson, T. M., Myers, B. J., \& Seburyamo, G. (2005). Insecticidal anthranilic diamides: A new class of potent ryanodine receptor activators. Bioorganic \& Medicinal Chemistry Letters, 15, 4898-4906.

Lasota, J. A., Shelton, A. M., Bolognese, J. A., \& Dybas, R. A. (1996). Toxicity of avermectins to diamondback moth (Lepidoptera: Plutellidae) populations: implications for susceptibility monitoring. Journal of Economic Entomology, 89, 33-38. doi.org/10.1093/jee/89.1.33.

McGovern, T. P., Gillenwater, H. B., \& McDonald, L. L. (1977). Repellents for adult Tribolium confusum: mandilates. Journal of the Georgia Entomological Society, 12, 79-84.

Nayak, M. K., Daglish, G. J., \& Byrne, V.S. (2005). Effectiveness of spinosad as a grain protectant against resistant beetle and psocid pests of stored grain in Australia. Journal of Stored Products Research, 41, 455-467. doi.org/10.1016/j.jspr.2004.07.002.

Negahban, M., Moharramipour, S., \& Sefidkon, F. (2006). Chemical composition and insecticidal activity of Artemisia Scoparia essential oil against three coleopteran stored-product Insects. Journal of Asia-Pacific Entomology, 9, 381-388.

Norhayu, A. (2015). Genetic diversity of tuba plants, and toxicity of their rotenoids formulated as Nano-Emulsion against Plutella xylostella L. PhD. Thesis, University Putra Malaysia, pp. 138.

Nukenine, E. N., Tofel, H. K., \& Adler, C. (2011). Comparative efficacy of neemazal and local botanicals derieved from Azadirachta indica and Plectranthus glandulosus against Sitophilus zeamais on maize. Journal of Pest Science, 84, 479-486. doi: 10.1007/s10340-011-0371-4.

Parimala, K. V., \& Maheswari, T. U. (2011). Evaluation of selected insecticides as seed protectants against the maize weevil (Sitophilus Zeamais M.). International Journal of Applied Biology and Pharmaceutical Technology, 2, 316-321.

Pathak, K. A., \& Jha, A. N. (1999). Toxicity of some insecticides against adults of Sitophilus oryzae, Sitophilus spp., \& Sitotroga cerealella. Indian Journal of Entomology, 61, 320-325.

Rahman, A., \& Talukder, F. (2006). Bio-efficacy of some plant derivatives that protect grain against the pulse beetle, Calloso bruchus maculatus. Journal of Insect Science, 3, 1-10.

Rajasekaran, B., \& Kumaraswami, T. (1985). Studies on increasing the efficacy on neem seed kernel extract. in Behavioural and Physiological Approaches in Pest Management, A. Regupathy and S. Jayaraj, Eds., pp. 29-30, Khadi and Village Industries Commission, Pune, India, 1985.

Rani, S., Tabassum, R., Naqvi, S. N. H., Ahmed, I., Sultan, B., \& Khan, M. F. (1997). Comparative toxicity of different formulation of cypermethrin, delmethrin and permethrin against Drosophila melanogaster (K.U strain). Journal of Environment Biology, 18(4), 343-349.

Rashid, M. A. (2012). Some aspects of biology in three Macrobrachium species. Lambert Academic Publishing, 2012.

Salgado, V. L. (1997). The modes of action of spinosad and other insect control products. Down to Earth, 52(1), 35-43.

Sarker, S., Latif, Z., \& Gray, A. (2006). Natural products isolation. Methods in Biotechnol. 20. Humana Press, Totawa, New Jersey, pp. 515.

Saunders, D. G., \& Bret, B. L. (1997). Fate of spinosad in the environment. Down to Earth, 52(1), 14-20.

Sparks, T. C., Crouse, G. D., \& Durst, G. (2001). Natural products as insecticides: the biology, biochemistry, and quantitative structure-activity relationships of spinosyns and spinosoids. Pest Manage. Sci., 57, 896-905. doi.org/10.1002/ps.358.

Spencer, D. S. C., Deen, S., \& Wilson, C. (2009). Economics of rice production in Sierra Leone: Report of a survey in three northern districts. Funded by the Soros Economic Development Fund (SEDF), New York, USA. Available online at http://www.eds-sl.com/docs/ (Accessed in September 2013), 2009. 
Srinivas, P., Lance, J. M., \& Timothy, M. N. (2003). Toxicity of insecticide-bait mixtures to insecticide resistant and susceptible western corn rootworms. Crop Protection, 22, 781-786. doi.org/10.1016/s0261-2194(03)00047-4.

Stark, J. D., \& Wennergren, U. (1995). Can population effects of pesticides be predicted from demographic toxicological studies? Journal of Economic Entomology, 88, 1089-1096. doi.org/10.1093/jee/88.5.1089.

Subramanyam, B., Toews, M., Ileleji, K. E., Maier, D. E., \& Thompson, G. D. (2006). Evaluation of spinosad as a grain protectant on three Kansas farms. Crop Protection, 26, 1021-1030.

Thaung, M., Myint, H., \& Collins, P. J. (1986). Joint Effects of Temperature and Insecticides on Mortality and Fecundity of Sitophilus oryzae (Coleoptera: Curculionidae) in Wheat and Maize. Journal of Economic Entomology, 79(4), 909-914.

Thompson, G. D., Dutton, R., \& Sparks, T. C. (2000). Spinosad, a case study: an example from natural products discovery programme. Pest Management Science, 56, 696-702.

Thompson, G. D., Michel, K. H., Yao, R. C., Sparks, T. C., \& Hutchins, S. H. (1997). The discovery of Saccharopolyspora spinosa and a new class of insect control products. Down to Earth, 52, 1-5.

Toews, M. D., \& Subramanyan, B. H. (2003). Contribution of contact toxicity and wheat condition to mortality of stored-product insects exposed to spinosad. Pest Management Science, 59, 538-544. doi.org/10.1002/ps.660.

Vayias, B. J., Athanassiou, C. G., Milonas, D. N., \& Mavrotas, C. (2009). Activity of spinosad against three stored product beetle species on four grain commodities. Crop Protection, 28(7), 561-566. doi.org/10.1016/j.cropro.2009.01.006. 